Tamaddun: Jurnal Sejarah dan Kebudayaan Islam, Vol. 8

Issue 2, Desember 2020

Avaliable online at

https://www.syekhnurjati.ac.id/jurnal/index.php/tamaddun/index

Published by Departement of History and Islamic Culture, Faculty of Ushuluddin Adab and Dakwah IAIN Syekh Nurjati Cirebon, Indonesia

\title{
Membangkitkan Jiwa Nasionalisme Generasi Millenial Dengan Mengurai Benang Sejarah Perjuangan Bangsa Indonesia
}

\section{Varidlo Fuad}

Jurusan Sejarah dan Kebudayaan Islam

Fakultas Ushuluddin, Adab, Dakwah

IAIN Syekh Nurjati Cirebon

\author{
v.fuad212@gmail.com
}

\begin{abstract}
Today, millennials' confidence in government is declining. This may be because there are no leaders and figures of the nation today who can exemple some of the figures of indonesia's independence struggle, as well as Sukarno who was still active as the first President of the Republic of Indonesia constrained by economic problems until finally making him to auction off one of his peci, as did Mohammad Hatta who was unable to be tempted by money and power because he always thought of his image as a leader and public figure, as with Mohammad Natsir who is famous as the leader and figure of the nation who from the beginning always chose to live a simple life because it seeks to be able to provide good suri tauladan for his people.
\end{abstract}

Keywords: Exemplary, Leader Figure, Nation Figure.

\begin{abstract}
ABSTRAK
Dewasa ini tingkat kepercayaan generasi millenial terhadap pemerintah semakin menurun. Hal tersebut mungkin terjadi karena belum adanya figur pemimpin dan tokoh bangsa saat ini yang dapat meneladani beberapa tokoh perjuangan kemerdekaan Indonesia, seperti halnya Soekarno yang saat itu masih aktif sebagai Presiden pertama Republik Indonesia terkendala masalah ekonomi hingga akhirnya membuatnya untuk melelang salah satu peci kepunyaanya, seperti halnya Mohammad Hatta yang pantang tergoda dengan uang dan kekuasaan karena selalu memikirkan citranya sebagai seorang pemimpin dan tokoh publik, seperti halnya Mohammad Natsir yang terkenal sebagai pemimpin dan tokoh bangsa yang sedari awal selalu memilih
\end{abstract}


untuk hidup sederhana karena berupaya untuk dapat memberikan suri tauladan yang baik bagi rakyatnya.

Kata Kunci: Keteladanan, Figur Pemimpin, Tokoh Bangsa.

\section{Pendahuluan}

Degradasi nilai yang terjadi di kalangan masyarakat pada era globalisasi semakin lama semakin memprihatinkan. Hal tersebut tercermin dari adanya perubahan kecenderungan Bangsa Indonesia yang menganut budaya ketimuran yang sering dijumpai pada masayarakat tempo dulu menjadi generasi yang lebih menunjukkan sisi "westernisasi" yang menitipkan nilai-nilai yang bertolak belakang dari nilai ketimuran kepada kaula muda yang kita kenal dengan nama generasi millennial pada saat ini. ${ }^{1}$

Sudah menjadi bukti sejarah bahwa dalam mencapai kemerdekaan Negara Kesatuan Republik Indonesia dapat terjadi dengan satu pemahaman persepsi tentang pentingnya persatuan dari seluruh pejuang bangsa dari Sabang sampai Merauke yang terikat secara geografis maupun kesamaan perasaan senasib sepenanggungan antar setiap anggota masyarakat tanpa memperdulikan agama, suku, jenis kelamin, bahkan baik yang berusia muda hingga usia tua untuk mewujudkan kemerdekaan yang ditandai dengan pidato heroik dari Sukarno pada saat Proklamasi Kemerdekaan, sekaligus menjadi hari lahir negara Indonesia yaitu pada tanggal 17 Agustus 1945. Perjuangan tersebut tidak dapat berhenti begitu saja tetapi harus terus dilanjutkan oleh setiap warganegara dengan membawa semangat kebangsaan seperti apa yang tertulis di dalam Pancasila maupun Pembukaan UUD 1945. Tetapi yang terjadi adalah maraknya tindak korupsi di negeri ini, lunturnya rasa persatuan dan gotong royong antar sesama bangsa Indonesia dengan ditandai adanya kerusuhan yang berlatar belakang

${ }^{1}$ Suharni Suharni, "Westernisasi Sebagai Problema Pendidikan Era Modern,” Jurnal ALIJTIMAIYYAH: Media Kajian Pengembangan Masyarakat Islam 1, no. 1 (2019): 73-88. 
perbedaan agama atau suku tertentu maupun sebenarnya publik sudah bisa menduga bahwa apa yang terjadi tersebut merupakan sebuah rekayasa sosial dalam menjamin kepentingan kelompok tertentu, sehingga memicu adanya ketidakpercayaan masyarakat dengan para pemangku kebijakan, hal ini sesuai dengan ungkapan Bung Karno bahwa "perjuanganku lebih mudah karena melawan penjajah, tapi perjuanganmu akan lebih sulit karena melawan bangsamu sendiri".

Apa yang terjadi dengan bangsa ini, yang dulu dikenal sebagai salah satu negara yang menjadi runutan bagi beberapa negara berkambang lainnya di era tahun 70-an di lingkup Asia Tenggara, berubah menjadi negara yang memiliki peringkat 85 terhadap Corruption Perception Index (CPI) dari total 180 negera yang ikut berpartisipasi pada riset tersebut ${ }^{2}$. Lalu bagaimana upaya yang perlu dilakukan untuk kembali menimbulkan rasa kepercayaan bagi warganegaranya terhadap NKRI, terlebih adanya tantangan globalisasi yang ditandai dengan kemudahan informasi dan teknologi yang saat ini sedang dialami oleh generasi millennial sehingga memudahkan masuknya budaya asing yang tidak sesuai dengan prinsip dasar kebudayaan negeri sendiri. Beberapa hal tersebut patut untuk dapat segera dijelaskan secara gamblang dalam rangka untuk menemukan solusinya, baik yang bersifat pencegahan maupun penanggulangan dalam menumbuhkembangkan common sense pada setiap warganegara untuk mengetahui peran pentingnya sebagai good citizen.

Tonggak perjuangan dalam mengisi kemerdekaan selalu menimbulkan kondisi dan tuntutan yang berbeda-beda sesuai dengan jamannya dan perjalanan panjang dalam mengisi kemerdekaan tersebut juga selalu diestafetkan dari satu generasi ke generasi berikutnya mau tidak mau, suka tidak suka akan tiba saatnya dengan apa yang saat ini marak disebut dengan generasi millennial untuk dapat memimpin kemana arah Indonesia ini akan bersandar, apakah

\footnotetext{
2 Transparency International, Peta Corruption Perception Index 2019, 2020, https://riset.ti.or.id/wp-content/uploads/2020/01/map-CPI-2019.pdf.
} 
sesuai dengan nilai-nilai Pancasila atau bahkan menjauh dari nilainilai tersebut.

Generasi millennial adalah sinonim dari generasi $\mathrm{Y}$ yang merupakan generasi yang lahir pada tahun 80-90an. Banyak istilah popular tentang generasi ini; connected or digital generation atau gen why yang identik dengan karakter berani, inovatif, kreatif, dan modern (Erkutlu, 2011). Definisi generasi menurut Kupperschmidt adalah suatu identitas kelompok dengan tahun kelahiran, masa (era) dan peristiwa bersejarah yang sama sebagai tahap kritis perkembangannya (Dries, Pepermans, De Kerpel, 2008). Empat generasi yakni Tradisionalis, Baby Boomers, Generasi X dan Generasi Y merupakan isu menarik dari tahun ke tahun dalam berbagai studi, di antaranya psikologi, manajemen, dan sumber daya manusia(Padgett, Gossett, Mayer, Chien, \& Turner, 2017). Secara merata generasi millennial mempunyai pendidikan yang lebih dari para Baby Boomers, mereka cukup terbiasa dengan teknologi bahkan sebagian besar dari mereka sangat ahli dengan teknologi. ${ }^{3}$

Globalisasi ditandai dengan pesatnya perkembangan ilmu pengetahuan dan teknologi, khususnya bidang informasi, komunikasi, dan transportasi. Hingga membuat dunia menjadi tidak memiliki dinding pemisah secara geografis dan seolah-olah membuat dunia menjadi satu kesatuan tanpa adanya batas wilayah masingmasing negara. Seperti yang dinyatakan oleh Princeton N. Lyman, globalisasi adalah pertumbuhan yang sangat cepat atas saling ketergantungan dan hubungan antara negara-negara di dunia dalam hal perdagangan dan keuangan ${ }^{4}$. Sedangkan menurut Giddens, bahwa globalisasi adalah adanya saling ketergantungan antara satu bangsa dengan bangsa lain, antara satu manusia dengan manusia lain melalui perdagangan, perjalanan, pariwisata, budaya, informasi, dan

\footnotetext{
${ }^{3}$ Amiroh Ambarwati and Susilo Teguh Raharjo, "Prinsip Kepemimpinan Character of A Leader Pada Era Generasi Milenial," PHILANTHROPY: Journal of Psychology 2, no. 2 (2018): 114.

${ }^{4}$ Kalfaris Lalo, "Menciptakan Generasi Milenial Berkarakter Dengan Pendidikan Karakter Guna Menyongsong Era Globalisasi,” Ilmu Kepolisian 12, no. 2 (2018): 68-75.
} 
interaksi yang luas sehingga batas-batas negara menjadi semakin sempit ${ }^{5}$.

Begitulah yang apabila kita rasakan saat ini, adanya kemudahan informasi melalui media sosial bahkan dapat bisa kita ketahui setiap detiknya terhadap kejadian-kejadian apa saja yang telah terjadi saat ini baik disekitar kita ataupun di belahan penjuru dunia lainnya ${ }^{6}$. Kemudahan atas akses informasi yang ditandai oleh perkembangan internet yang semakin pesat disertai minat yang besar dapat memberikan hasil yang baik maupun buruk bagi mereka yang bergantung dari aktivitas online yang mereka lakukan sewaktu mereka mengakses internet ${ }^{7}$. Keadaan tersebut perlu diberikan perhatian karena tentu memiliki sisi positif maupun sisi negatifnya dan hal tersebutlah yang menjadi respon dari salah satu kebijakan yang dibuat oleh pemerintah melalui Undang-Undang Nomor 11 Tahun 2008 Tentang Informasi dan Transaksi Elektronik (UU ITE) yang juga semakin dipertegas melalui Peraturan Menteri Komunikasi dan Informatika Republik Indonesia Nomor 19 Tahun 2014 Tentang Penanganan Situs Internet Bermuatan Negatif, salah satu Pasal di dalam peraturan tersebut menjelaskan tujuan dari Peraturan ini adalah untuk memberikan dasar bagi pemerintah dan masyarakat terhadap pemahaman situs internet bermuatan negatif dan peran bersama dalam penanganannya dan melindungi kepentingan umum dari konten internet yang berpotensi memberikan dampak negatif dan atau merugikan (Pasal 2a dan $b)$.

\footnotetext{
${ }^{5}$ Anthony Giddens, The Consequences of Modernity - Anthony Giddens - Google Kitaplar, 2016, http://voidnetwork.gr/wp-content/uploads/2016/10/The-Consequences-of-Modernityby-Anthony-

Giddens.pdf\%0Ahttps://books.google.com/books?hl=tr\&lr=\&id=SVmkJEwWGwAC\&oi=fn $\mathrm{d} \& \mathrm{pg}=\mathrm{PT} 45 \& \mathrm{dq}=$ modernity + consequences + giddens $\&$ ots $=5 \mathrm{jp} 0 \mathrm{oDSRFL} \& \mathrm{sig}=\mathrm{nE} 59 \mathrm{fOsYM} 2$ RKETZDHXjPZwjYk1.

${ }^{6}$ Dinda Larasati, "Globalisasi Budaya Dan Identitas : Pengaruh Dan Eksistensi Hallyu ( KoreanWave ) versus Westernisasi Di Indonesia," Jurnal Hubungan Internasional 11, no. 1 (2018): 109-120, https://e-journal.unair.ac.id/JHI/article/view/8749.

${ }^{7}$ Astuti Nur Qomariyah, "Perilaku Penggunaan Internet Dikalangan Remaja Diperkotaan" (2009).
}

Tamaddun: Jurnal Sejarah dan Kebudayaan Islam, Volume (8), Issue (2), Desember 2020 
Kemudahan memperoleh informasi ini agaknya menjadi suatu hal yang penting untuk diperhatikan oleh pemerintah bahkan setiap warganegara terlebih atas beberapa fenomena-fenomena yang terjadi saat ini seperti banyaknya pemberitaan dimedia online yang cenderung untuk mengadudomba antar warganegara Indonesia untuk kepentingan kelompok tertentu atau yang saat ini kita kenal dengan istilah hoax/berita palsu, saling hujat dan fitnah, black campaign, dan berbagai prilaku negatif lainnya. Hal tersebut juga senada dengan hasil riset yang dilakukan oleh Asosiasi Penyelenggara Jasa Internet Indonesia (APJII) ${ }^{8}$ mengenai penggunaan internet yang menyatakan bahwa $80 \%$ pengguna internet dilakukan oleh generasi muda dengan rentang usia di bawah 30 tahun. Survei tersebut juga berupaya untuk mengetahui perilaku pengguna internet bahwa keamanan berinternet bagi usia anak hanya sebesar 22,9\% sedangkan $76,4 \%$ menyatakan beresiko bagi keamanan anak. Jika informasi yang didapatkan sebagian besar digunakan hanya untuk kepentingan kelompok tertentu dan lebih menjurus kepada ajakan yang bersifat negatif tentu lambat laun akan dapat memberikan dampak negatif kepada perkembangan para pengguna internet seperti yang diutarakan oleh Rene Hobbs (1998) "Should media literacy education aim to protect children and young people from negatif media influences" yang saat ini cenderung marak digunakan oleh generasi millenial.

Hal - hal di atas yang disebutkan oleh penulis pada akhirnya akan memunculkan kecenderungan terjadinya disorientasi nilai karena adanya perubahan-perubahan yang terjadi di dalam sistem tata nilai masyarakat saat ini menjadi hal-hal yang sudah tidak dapat terelakkan lagi dengan adanya globalisasi, tidak ada lagi masyarakat pedesaan maupun masyarakat perkotaan yang ada hanyalah menuju masyarakat modern sehingga menyebabkan masyarakat Indonesia

\footnotetext{
${ }^{8}$ Wibowo Heru Prasetiyo, "DARURAT LITERASI MEDIA DALAM DIGITAL CITIZENSHIP : SATU GAGASAN MENUJU WARGA NEGARA MELEK INFORMASI" (Asosiasi Profesi Pendidikan Pancasila dan Kewarganegaraan Indonesia (AP3KnI), 2016), 8.
} 
khususnya generasi millenial mengalami kegoyahan konseptual tentang prinsip-prinsip kehidupan yang telah mengakar lama menjadi pegangan hidup menjadi kabur ditengah-tengah arus moderniasasi yang lebih menonjolkan sikap pragmatis maupun individualistik. Padahal, kelangsungan hidup negara dan bangsa Indonesia di era globalisasi, mengharuskan kita untuk melestarikan nilai-nilai Pancasila, agar generasi penerus bangsa tetap dapat menghayati dan mengamalkannya dan agar intisari nilai-nilai yang luhur itu tetap terjaga dan menjadi pedoman bangsa Indonesia sepanjang masa bukan malah sebaliknya. ${ }^{9}$

Indonesia merupakan negara yang luar biasa kaya, kaya dalam hal jumlah penduduknya, keberagaman kebudayaannya, begitu pula dengan keadaan wilayahnya yang amat sangat beragam. Namun, banyaknya perbedaan tersebut bukanlah sebagai kendala namun sebagai suatu tanda besarnya kakayaan yang dimiliki oleh negeri ini dan bahkan para pejuang dan pahlawan kemerdekaan dengan berbagai keterbatasan yang mereka miliki pada saat itu mampu untuk mewujudkan Indonesia yang bersatu demi meraih kemerdekaan Indonesia. Terwujudnya kemerdekaan Indonesia bukan semata-mata pemberian oleh pihak asing tetapi bagaimana seluruh elemen masyarakat dapat bersatu tanpa memandang agama, suku, ataupun golongan tertentu dan mampu bekerjasama, gotong royong dalam meraih kemerdekaan. Nilai-nilai tersebutlah yang perlu dikuatkan oleh generasi millenial saat ini, melalui sejarah perjuangan bangsa Indonesia diharapkan dapat memberikan gambaran betapa luar biasanya nilai-nilai nasionalisme yang ditunjukkan oleh para pahlawan tanpa memandang adanya kepentingan pribadi atau golongan tetapi untuk kepentingan bangsa Indonesia.

\footnotetext{
${ }^{9}$ Ambiro Puji Asmaroini, "Menjaga Eksistensi Pancasila Dan Penerapannya Bagi Masyarakat Di Era Globalisasi," Jurnal Pancasila Dan Kewarganegaraan 1, no. 2 (2017): $1-14$.
} 


\section{Metode}

Metode penelitan yang digunakan oleh penulis adalah dengan menggunakan pendekatan kualitatif dan bersifat deskriptif. Penelitian kualitatif merupakan kegiatan berpikir sistemik sebagai upaya untuk mendapatkan kebenaran ilmiah melalui kegiatan inquiri. Penulisan ini dilakukan melalui berbagai rujukan pada berbagai sumber kepustakaan dan fenomena sosial yang terjadi di masyarakat. Sumber kepustakaan yang digunakan dalam penelitian ini diperoleh dari buku, jurnal, internet serta hasil penelitian terdahulu. Dalam menggali informasi pada penulisan karya ilmiah ini, penulis memperoleh informasi dari dokumen-dokumen yang dapat memenuhi kaidah-kaidah dokumen ilmiah yang dapat dipertanggungjawabkan. Dokumen dibutuhkan untuk menelaah secara mendalam sehingga dapat mendukung dan menambah kepercayaan dan pembuktian suatu kejadian (Al Muchtar, 2015: 3) Al Muchtar, S. (2015) “Dasar Penelitian Kualitatif". Bandung: Gelar Pustaka Mandiri

\section{Pembahasan dan diskusi}

3.1. Tantangan: Internalisasi Jiwa Nasionalisme bagi Generasi Millenial

Sepanjang beberapa dekade Bangsa Indonesia telah mengukuhkan diri sebagai bangsa yang merdeka tidak lantas membuat apa yang sudah dicita-citakan oleh para pendiri bangsa sirna begitu saja, melainkan kemerdekaan adalah start/dimulainya cetak biru yang bernama Pancasila untuk dapat diamanatkan oleh setiap tumpah darah Indonesia. Nyatanya, pengamanatan tersebut tidak dapat berjalan dengan sewajarnya karena tentu mendapatkan tantangan dari perkembangan modernisasi yang berintikan perkembangan teknologi untuk dapat memudahkan pekerjaan manusia dalam hal apapun, terkhusus teknologi informasi yang sebegitu pesatnya bertransformasi sebagai media pertukuran informasi publik dari berbagai manusia di penjuru dunia sehingga 
memungkinkan adanya pertukaran antar budaya yang terjadi dari hasil mencerna informasi tersebut.

Selain memberikan dampak positif, Modernisasi juga memberikan dampak negatif diantaranya (1) pesatnya pertumbuhan industri yang berdampak pada melimpahnya penyediaan barang kebutuhan masyarakat sehingga membuat kecenderungan pola hidup masyarakat menjadi lebih konsumtif sehingga tidak jarang hal tesebut menjadi jurang pembeda antara si kaya dengan kemampuan tingkat konsumtif yang lebih tinggi dibandingkan dengan si miskin dengan kemampuan tingkat konsumtif yang lebih rendah;(2) dengan adanya kemudahan teknologi membuat sebagian besar masyarakat merasa tidak lagi membutuhkan orang lain dalam kegiatan aktivitasnya sehari-hari sehingga membuat perkembangan masyarakt lebih bersikap individualistik;(3) bahkan adanya tren yang saat ini sedang digandrungi oleh generasi millenial mengenai penerapan budaya barat yang mulai menggeser budaya asli Indonesia seperti seorang yang lebih muda tidak lagi menghormati kepada orang yang lebih tua, kehidupan bebas remaja, maupun kegemaran remaja yang lebih menyukai dance dan lagu barat dibandingkan dengan lagu dan tarian asli Indonesia. ${ }^{10}$

Tentu saja hal tersebut menjadi beberapa permasalahan karena bertentangan dengan nilai-nilai yang ada di dalam Pancasila seperti humanisme maupun gotong royong. Berbeda halnya dengan apa yang telah ditunjukan oleh para pahlawan bangsa Indonesia yang menjunjung persatuan dan kesatuan atas dasar perasaan senasib sepenanggungan mengenai pahitnya penjajahan yang mungkin tidak lagi dirasakan oleh generasi penerus bangsa Indonesia karena tidak bersentuhan langsung dengan kejadian tersebut, sedangkan disatu sisi untuk menjaga eksistensi suatu bangsa dan negara perlu adanya kehidupan masyarakat yang memiliki karakter dan budaya yang kuat ${ }^{11}$,

${ }^{10}$ M. Husin Affan and Hafidh Maksum, "Membangun Kembali Sikap Nasionalisme Bangsa Indonesia Dalam Menangkal Budaya Asing Di Era Globalisasi," Jurnal Pesona Dasar 3, no. 4 (2016): 65-72.

${ }^{11}$ Imam Suyitno, "Pengembangan Pendidikan Karakter Dan Budaya Bangsa Berwawasan Kearifan Lokal," no. 1 (2012): 1-13.

Tamaddun: Jurnal Sejarah dan Kebudayaan Islam, Volume (8), Issue (2), Desember 2020 
namun disisi yang lain karena luar biasanya keberagaman budaya yang dimiliki oleh bangsa Indonesia banyak pula faktorfaktor yang dapat memecah belah bangsa ini karena sumbu pemersatu berdasarkan kepada perasaan senasib sepenanggungan tersebut. Dewasa ini juga menambah adanya permasalahan mengenai ketidakpercayaan para generasi muda yang dalam tulisan ini diwakili oleh generasi millenial terhadap pemerintah, yang tentu saja hal tersebut tidak terjadi begitu saja namun berdasarkan beberapa hal yang mengindikasikan adanya pejabat publik yang tidak menyadari posisinya baik sebagai agen-agen pemerintah yang semestinya dapat memberikan contoh kepada masyarakat tentang bagaimana menjunjung tinggi moral, integritas, maupun profesional mereka yang tidak dapat disamakan dengan posisi seorang warga negara biasa. Sehingga tidak heran apabila melihat kondisi tersebut, jikalau persatuan masih menjadi suatu hal yang mahal dinegeri ini karena minimnya figur yang dapat memberikan contoh yang baik bagi masyarakat.

Dengan mencerna situasi tersebut, penulis berupaya untuk mengaitkan pentingnya masalah kepemimpinan nasional dalam menghadapi isu sentral pada masa-masa perjuangan kemerdekaan Indonesia. Hal ini berdasarkan kecenderungan historiografi konvensional Indonesia yang berorientasikan dimana terjadinya peristiwa-peristiwa penting dan perubahan sosial itu dalam banyak hal digerakkan oleh orang-orang hebat dibelakangnya yang dikenal dengan istilah the great man theory ${ }^{12}$. Orang - orang hebat pada era perjuangan kemerdekaan di awal abad ke-20 diantaranya Soekarno (lahir 1901) dan Mohamad Hatta (lahir 1902) adalah mereka yang lahir dan mengalami masa-masa critically seperti zaman Etische Politiek (1901-1918), Zaman Bergerak (1908-1942), Zaman Jepang (1942-1945), dan Zaman Revolusi Indonesia (1945-1950) yang pada akhirnya ditakdirkan oleh sejarah sebagai primus novus (pemimpin baru)

\footnotetext{
12 Andi Suwirta and Iyep Candra Hermawan, "Masalah Karakter Bangsa Dan Figur Kepemimpinan Di Indonesia : Perspektif Sejarah,” Atikan 2, no. 1 (2012): 133-154. 
dalam mencita-citakan (to imagine) dan mewujudkan (to realize) negara-bangsa baru yang bernama Republik Indonesia ${ }^{13}$.

Maka dari itu menjadi penting untuk dapat meneladani hal - hal besar apa yang telah dilakukan oleh para pahlawan bangsa untuk bergerak dan menyatukan seluruh elemen masyarakat dalam upaya mewujudkan kemerdekaan Indonesia, sehingga tidak salah jika penulis mencoba untuk meminjam sepenggal pidato yang telah dilontarkan oleh Bung Karno pada saat hari kemerdekaan 17 Agustus 1966 "Djangan Sekali-kali Meninggalkan Sedjarah".

3.2. Keteladanan Pahlawan Bangsa Indonesia: Sebagai Penguat Jiwa Nasionalisme dalam Sejarah Perjuangan Bangsa Indonesia

Layaknya orang tua kepada anak, semuanya memang bisa diawali dari kata-kata, namun tidak cukup hanya dengan katakata tetapi juga harus dibuktikan melalui prilaku sebagai bukti nyata, begitupun juga antara pemerintah dan warganegaranya. Masyarakat membutuhkan suatu figur yang dapat memberikan hal-hal baik terutama dalam pengamalan nilai-nilai Pancasila, sehingga Pancasila bukan hanya sebagai jargon ceremonial belaka yang diucapkan pada hari senin pada saat upacara sekolah namun juga di amalkan oleh para pemimpin dan tokoh bangsa sebagai bukti eksistensi Pancasila.

Keteladanan yang ditunjukkan/dicontohkan oleh para pemimpin dan tokoh bangsa tersebut juga menjadi suatu hal yang penting untuk dapat mewujudkan masyarakat yang Pancasilais sebagai perwujudan jati diri bangsa yang sesungguhnya. Alih-alih dapat mewujudkan hal tersebut, para pemimpin dan tokoh bangsa dinilai tidak dapat mengetahui posisinya sebagai pejabat publik dimana sebagian besar kegiatannya seharusnya untuk kepentingan seluruh rakyat

${ }^{13}$ Andi Suwirta, "Memahami Dan Menghargai Perjuangan R . Soediro Wirjo Soehardjo Dalam Historiografi Indoensia," in Sejarah Dan Pendidikan Sejarah: Perspektif Malaysia Dan Indonesia (UNPAD, 2006), 97-105. 
namun faktanya masih banyak ditemukan pejabat publik yang terlibat dalam tindak korupsi ${ }^{14}$.

Menjadi pejabat publik tidak dapat disamakan dengan masyarakat biasa. Menjadi pejabat publik harus siap bahwa segala tindak tanduk prilaku atau aktivitas mereka merupakan suri tauladan bagi masyarakatnya. Jika moralitas yang hadir di masyarakat bersebrangan dengan nilai-nilai Pancasila bisa jadi merupakan turunan dari adanya praktek tuna moral yang diperlihatkan oleh para pejabat publiknya, sehingga tidak salah jika mengatakan bahwa moralitas suatu bangsa dapat tercermin dari para pemimpin dan tokoh bangsanya.

Suksesnya perjuangan seluruh tumpah darah Indonesia dalam mewujudkan Indonesia sebagai negara yang merdeka tentu tidak terlepas dari peran serta tokoh-tokoh pemimpin bangsa sebagai poros perjuangan. Telah tercatatkan dalam sejarah bangsa Indonesia mengenai nama-nama mereka yang berjasa besar dalam proses perjuangan kemerdekaan Indonesia. Jasa-jasa tersebut terwujud dalam gerakan aksi dan mobilisasi masa seluruh rakyat yang telah diikat melalui satu pertalian Soempah Pemoeda dengan diikuti keyakinan dan kepercayaan penuh dari setiap partisipannya. Keyakinan dan kepercayaan ialah salah satu kuncinya, dan melalui suri tauladan yang dicontohkan oleh tokoh pemimpin bangsalah yang pada akhirnya menciptakan rasa yakin dan percaya pada diri seluruh rakyat Indonesia.

Seperti halnya dengan Soekarno. Siapa yang tidak kenal dengan tokoh bangsa yang satu ini. Selain beliau pernah menjabat sebagai Presiden pertama Republik Indonesia

\footnotetext{
${ }^{14}$ Dari hasil laporan tahunan KPK tahun 2018 dan 2019 masing-masing menunjukan tingginya jumlah tersangka OTT (Operasi Tangkap Tangan) yaitu 121 orang dan 76 orang yang melibatkan para pejabat publik baik dari lembaga eksekutif, yudikatif, maupun legislatif. KPK, Laporan Tahunan Komisi Pemberantasan Korupsi Tahun2018, 17 Mei 2019, 2018, https://www.kpk.go.id/id/publikasi/laporan-tahunan/934-laporan-tahunan-kpk2018.KPK, Laporan Tahunan KPK 2019, Kpk, 2019.
} 
nyatanya Soekarno pernah melelang peci hitamnya dikarenakan terdesak masalah ekonomi untuk membayar zakat fitrah. Terlebih kejadian tersebut terjadi pada saat beliau masih aktif sebagai seorang Presiden yang notabene, jiakalau yang bersangkutan berupaya untuk memanfaatkan kedudukan maupun statusnya tentu dapat dengan sangat mudah bagi Soekarno dapat menunaikan zakat fitrah tersebut. Namun kenyataan berkata lain, yang akhirnya membuat Soekarno melelang sebuah pecinya atas saran dari Roeslan Abdoelgani. Roeslan tidak berupaya sendiri dalam kegiatan lelang peci tersebut, proses lelang diserahkan kepada Anang (keponakan dari Roeslan) yang merupakan pengusaha peci merk Kuda Mas yang sering dipakai oleh Soekarno. Singkat cerita, hasil dari lelang tersebut mencapai nilai 10 juta rupiah yang sontak membuat Soekarno kaget. Setelah mendengarkan cerita kejadian yang sebenarnya dari Roeslan, Soekarno semakin terkejut karena bukan hanya satu namun ada tiga peci yang dilelang pada saat itu atas inisiatif dari Anang, bahkan dua peci lainnya bukanlah peci asli milik Soekarno melainkan peci baru yang sengaja dibuat sedemikian rupa sehingga menjadi peci seperti bekas pakai. Mendengar hal tersebut Soekarno spontan berkata "kurang ajar Anang, kalau begitu yang berdosa saya atau Anang?", "Anang" timpal Roeslan yang lanjut menanyakan kembali "uang begitu banyak mau dipakai untuk apa?", "untuk zakat fitrahku, bawalah semua uang ini ke makam Sunan Giri, bagikan kepada orangorang miskin disana"15. Hal tersebut membuktikan sekecil apapun penyalahgunaan pangkat, status, maupun kedudukan tidak dapat dibenarkan, terlebih bagi mereka yang telah diamanati sebagai pejabat publik.

Semakin besar jabatan maupun semakin tinggi kedudukannya maka semakin berat pula tanggung jawab yang

${ }^{15}$ Kadjat Adrai, Suka Duka Fatmawati Sukarno: Seperti Dicerikatan Kepada Kadjat Adrai (Jakarta: Yayasan Bung Karno, 2008).

Tamaddun: Jurnal Sejarah dan Kebudayaan Islam, Volume (8), Issue (2), Desember 2020 
diemban oleh wakil rakyat tersebut. Seperti kisah yang satu ini, karena tidak lengkap jika menyebut Soekarno tanpa bercerita mengenai Wakil Presiden Indonesia pertama, Mohammad Hatta. Selain dikenal cerdas dan piawai dalam bidang ekonomi, Moh. Hatta juga dikenal sebagai sosok berintegritas tinggi yang tidak gila akan jabatan. Moh. Hatta juga pantang tergoda akan uang maupun kekuasaan bahkan setelah pengunduran dirinya sebagai Wakil Presiden pertama Indonesia pada tanggal 1 Desember 1956 banyak tawaran dari perusahaan Belanda untuk menjadikannya sebagai komisaris, tetapi beliau menolak karena malu dan tidak mau dinilai oleh rakyat sebagai seorang yang hanya mementingkan kepentingan pribadi dan tidak memperhatikan kepentingan negara ${ }^{16}$. Citra seperti inilah yang seharusnya ditunjukkan oleh pemimpin bangsa karena merupakan warisan penting dan akan selalu dapat diingat oleh rakyatnya, baik pada saat diangkat hingga selesai tugasnya untuk memberikan yang terbaik bagi rakyat.

Selain kedua tokoh bangsa tersebut, banyak dari tokohtokoh bangsa pada masa lalu yang dapat dipelajari untuk dapat dijadikan sebagai suri tauladan. Satu diantaranya adalah Mohammad Natsir. Mohammad Natsir pernah menjabat sebagai Perdana Menteri pada era Demokrasi Parlementer (6 September 1950). Mohammad Natsir juga dikenal sebagai pejabat publik yang sangat sederhana bahkan pada saat perjumpaanya pertama kali dengan Guru Besar dari Universitas Cornel, George McTurnan Kahin begitu kagum dengan penampilan Natsir yang pada saat itu menjabat sebagai Menteri Penerangan namun jauh dari kesan kemewahan yang terlihat dari penampilannya yang mengenakkan jas bertambal ${ }^{17}$.

${ }^{16}$ Adhe Firmansyah, Hatta : Si Bung Yang Jujur \& Sederhana, ed. Rose Kusumaningratri, Cet. 1. (Jogjakarta: Garasi House of Book, 2010).

${ }^{17}$ Abd Rahman, "PENDIDIKAN SEJARAH DAN KARAKTER BANGSA BELAJAR KETELADANAN HIDUP DARI KETOKOHAN NATSIR DAN BUYA HAMKA" 15, no. 3 (2013): 337-347.

Tamaddun: Jurnal Sejarah dan Kebudayaan Islam, Volume (8), Issue (2), Desember 2020 
Sewaktu masih menimba ilmu dan belum menjadi Perdana Menteri maupun Menteri Penerangan, Mohammad Natsir adalah orang yang cerdas dan memiliki potensi intelektual yang meumpuni dengan dibuktikan ia mampu mendapatkan beasiswa senilai Rp. 130 dari Pemerintah Hindia Belanda, namun karena ia menyadari jika ia menerima beasiswa tersebut yang notabene berasal dari Pemerintah Hindia Belanda maka ia secara langsung menerima uang beasiswa dari penjajah dan ikut membenarkan penjajahan itu sendiri. Sehingga pada akhirnya Natsir lebih memilih untuk mengabaikan kesempatan tersebut dan lebih memilih untuk menjadi guru agama dan jurnalis ${ }^{18}$ walaupun dengan gaji yang lebih rendah. Hidup sederhana sudah merupakan gaya hidup yang dipilih oleh Natsir sedari awal, ia paham bahwa menjadi pejabat negara tidaklah selalu berorientasi untuk mendapatkan kehidupan yang mewah tetapi lebih daripada itu menjadi pejabat publik wajib memberikan suri tauladan yang baik untuk rakyat yang diperjuangkannya.

\section{Simpulan}

Adanya berbagai tantangan dalam pembentukan generasi millenial yang sesuai dengan nilai-nilai Pancasila, seperti dampak buruk dari perkembangan moderninsasi yang mengakibatkan rendahnya nasionalisme ganerasi millenial dari hasil proses pencernaan nilai-nilai dan budaya yang tidak sesuai dengan budaya sendiri sebagai bentuk kemudahan akses informasi dan diperburuk dengan rendahnya tingkat kepercayaan generasi muda yang dalam hal ini diwakili oleh generasi millenial terhadap pemerintah, karena pemerintah dirasa tidak lagi dapat memberikan contoh yang baik bagi masyarakat.

Jika tokoh bangsa hari ini mampu untuk meneladani nilai-nilai kehidupan yang pernah dicontohkan Soekarno, Moh. Hatta, M. Natsir dan para tokoh perjuangan kemerdekaan Indonesia yang telah

\footnotetext{
${ }^{18}$ Ibid.
}

Tamaddun: Jurnal Sejarah dan Kebudayaan Islam, Volume (8), Issue (2), Desember 2020 
berkorban segalanya untuk tanah air Indonesia, tentu bangsa Indonesia akan jauh lebih damai dan siap dalam mengahadapi era komunikasi saat ini yang mana tidak lagi rakyat semakin terpecah belah dan terkotak-kotak berdasarkan perbedaan yang ada melainkan menjadi satu kekuatan yang luar biasa dalam bingkai kebhinekaan Indonesia.

Pentingnya figur yang dapat mengamalkan nilai-nilai keteladanan menjadi satu kunci utama untuk mewujudkan generasi millenial yang Pancasilais, yang bukan hanya sekedar hafalan pada setiap butir Pancasila tetapi juga dapat mengamalkan pada kehidupannya di dunia nyata. Jika moralitas yang hadir di masyarakat bersebrangan dengan nilai-nilai Pancasila bisa jadi merupakan turunan dari adanya praktek tuna moral yang diperlihatkan oleh para pejabat publiknya, sehingga tidak salah jika mengatakan "jangan menuntut lebih kepada rakyat jika mereka yang menjadi pemimpin tidak mampu menjadi figur yang baik bagi masyarakat". Karena menjadi seorang pejabat publik merupakan pemimpin dan tokoh bangsa sehingga citra yang ditampilkan akan menjadi warisan dan selalu diingat oleh rakyatnya.

\section{References}

Adrai, Kadjat. Suka Duka Fatmawati Sukarno: Seperti Dicerikatan Kepada Kadjat Adrai. Jakarta: Yayasan Bung Karno, 2008.

Affan, M. Husin, and Hafidh Maksum. "Membangun Kembali Sikap Nasionalisme Bangsa Indonesia Dalam Menangkal Budaya Asing

Di Era Globalisasi." Jurnal Pesona Dasar 3, no. 4 (2016): 65-72.

Ambarwati, Amiroh, and Susilo Teguh Raharjo. "Prinsip Kepemimpinan Character of A Leader Pada Era Generasi Milenial." PHILANTHROPY: Journal of Psychology 2, no. 2 (2018): 114.

Asmaroini, Ambiro Puji. "Menjaga Eksistensi Pancasila Dan Penerapannya Bagi Masyarakat Di Era Globalisasi." Jurnal

Pancasila Dan Kewarganegaraan 1, no. 2 (2017): 1-14.

Firmansyah, Adhe. Hatta: Si Bung Yang Jujur \& Sederhana. Edited by

Tamaddun: Jurnal Sejarah dan Kebudayaan Islam, Volume (8), Issue (2), Desember 2020 
Rose Kusumaningratri. Cet. 1. Jogjakarta: Garasi House of Book, 2010.

Giddens, Anthony. The Consequences of Modernity - Anthony Giddens Google Kitaplar, 2016. http://voidnetwork.gr/wpcontent/uploads/2016/10/The-Consequences-of-Modernity-byAnthony-

Giddens.pdf\%0Ahttps://books.google.com/books?hl=tr\&lr=\&id $=S V m k J E w W G w A C \& o i=$ fnd $\& p g=P T 45 \& d q=$ modernity + consequ ences+giddens\&ots $=5 j$ p0oDSRFL\&sig $=n E 59 f O s Y M 2 R K E T Z D H X j$ PZwjYk1.

KPK. Laporan Tahunan Komisi Pemberantasan Korupsi Tahun2018. 17 Mei 2019, 2018. https://www.kpk.go.id/id/publikasi/laporantahunan/934-laporan-tahunan-kpk-2018.

- - - . Laporan Tahunan KPK 2019. Kpk, 2019.

Lalo, Kalfaris. "Menciptakan Generasi Milenial Berkarakter Dengan Pendidikan Karakter Guna Menyongsong Era Globalisasi." Ilmu Kepolisian 12, no. 2 (2018): 68-75.

Larasati, Dinda. "Globalisasi Budaya Dan Identitas: Pengaruh Dan Eksistensi Hallyu ( KoreanWave) versus Westernisasi Di Indonesia." Jurnal Hubungan Internasional 11, no. 1 (2018): 109120. https://e-journal.unair.ac.id/JHI/article/view/8749.

Prasetiyo, Wibowo Heru. "DARURAT LITERASI MEDIA DALAM DIGITAL CITIZENSHIP : SATU GAGASAN MENUJU WARGA NEGARA MELEK INFORMASI." 8. Asosiasi Profesi Pendidikan Pancasila dan Kewarganegaraan Indonesia (AP3KnI), 2016.

Qomariyah, Astuti Nur. "Perilaku Penggunaan Internet Dikalangan Remaja Diperkotaan" (2009).

Rahman, Abd. "PENDIDIKAN SEJARAH DAN KARAKTER BANGSA BELAJAR KETELADANAN HIDUP DARI KETOKOHAN NATSIR DAN BUYA HAMKA" 15, no. 3 (2013): 337-347.

Suharni, Suharni. "Westernisasi Sebagai Problema Pendidikan Era Modern." Jurnal AL-IJTIMAIYYAH: Media Kajian Pengembangan Masyarakat Islam 1, no. 1 (2019): 73-88.

Suwirta, Andi. "Memahami Dan Menghargai Perjuangan R . Soediro Wirjo Soehardjo Dalam Historiografi Indoensia." In Sejarah Dan Pendidikan Sejarah: Perspektif Malaysia Dan Indonesia, 97-105. UNPAD, 2006.

Tamaddun: Jurnal Sejarah dan Kebudayaan Islam, Volume (8), Issue (2), Desember 2020 
Suwirta, Andi, and Iyep Candra Hermawan. "Masalah Karakter Bangsa Dan Figur Kepemimpinan Di Indonesia: Perspektif Sejarah." Atikan 2, no. 1 (2012): 133-154.

Suyitno, Imam. "Pengembangan Pendidikan Karakter Dan Budaya Bangsa Berwawasan Kearifan Lokal," no. 1 (2012): 1-13.

Transparency International. Peta Corruption Perception Index 2019, 2020. https://riset.ti.or.id/wp-content/uploads/2020/01/mapCPI-2019.pdf.

Tamaddun: Jurnal Sejarah dan Kebudayaan Islam, Volume (8), Issue (2), Desember 2020 